\title{
LIPID CONTENT OF TUMORS
}

\author{
BY MORIO YASUDA 1 AND W. R. BLOOR
}

(From the Department of Biochemistry and Pharmacology, University of Rochester School of Medicine and Dentistry, Rochester, New York)

(Received for publication March 9, 1932)

\section{INTRODUCTION}

Studies bearing on the lipids of tumors have been made in most cases either with regard to the changes of the lipid content of the blood of tumor animals and patients or the relation between the lipids and the growth of the tumors.

Of the lipids, cholesterol has been most frequently studied. Roffo (1) reported that cholesterol is concerned with the development of experimental tumors and that an increase of cholesterol in blood plasma characterizes the so-called precancerous stage. Also the cells of malignant tumors cause considerable destruction of absorbed cholesterol. Mattick and Buchwald (2) found hypercholesterolemia in the plasma of cancer patients with little change in the content of the corpuscles. They found also an accumulation of total fatty acids in the plasma. Kahn (3) showed that malignant tumors contained large amounts of cholesterol and its esters while the cholesterol content of the blood serum was lower than normal. Bolaffi (4) could not find any particular change in the cholesterol content of the blood of tumor mice, but found an increase of cholesterol ester in the whole organism. Burgheim (5) by histochemical examination found larger amounts of cholesterol in malignant tumors than in benign ones and also found a temporary increase of cholesterol in the blood of cancer patients after treatment by x-rays. He believed that this increase of cholesterol in the blood was caused by the destruction by the $\mathrm{x}$-rays of cells containing large amounts of cholesterol.

Phosphorus of the blood of the tumor animals interested Haam (6), Enselme (7) and Roffo (8) who made studies of the phospholipids and nucleoproteins.

The lipids of tumor tissue were first investigated by Bullock and Cramer (9) who found that they showed both quantitative and qualitative differences in different strains of tumors and that rapidly growing tumors contained more phospholipid and less cholesterol than the slowly growing ones.

${ }^{1}$ Fellow in Biochemistry of the Rockefeller Foundation on leave from the Institute of Biochemistry, Tokyo Imperial University. 
Regarding the influence of the lipids on the growth of tumors little can be said despite a good many investigations. Maisin (10) stated in his recent work that diet can influence the appearance and evolution of tar cancer. Preceding closely the development of tar cancer and during its evolution, the metabolism of fat is defective as shown by cholesterinemia. Feeding of liver lipids or ether extract of liver has no accelerating effect on the growth of the tumor, but rather an inhibiting one when compared with a raw beef muscle or a purely vegetarian diet. A diet of brain, rich in lipids, seems to have the same inhibiting action on tar cancer as liver lipids and to an even greater extent. Rondoni (11) injected cholesterol suspended in guinea pig serum and physiological sodium chloride solution into rats inoculated with tumors and found that it unquestionably promoted the growth of the tumor, whereas lecithin showed itself to be an inhibitor of the tumor growth. The acetone extract of tissues promoted growth. Friedberger and Simke (12) concluded that the growth of the tumor is dependent upon the quantity and quality of the diet. A deficient diet or any diet which causes malnutrition of the animals prevents the growth of tumors. Similar statements have been made by other investigators, Caspari and Ottensooser (13) and others.

The present communication is a preliminary report chiefly concerned with the lipid contents of various tumors with reference to their physiological or pathological significance.

\section{LIPID CONTENT OF VARIOUS TUMORS}

\section{Materials and methods}

The materials used were both human and animal tumors. The former were mostly obtained by surgical operation, a few at autopsy. The animal tumor was the Mouse Adenocarcinoma of Buffalo Strain 3. The tumors, as soon as possible after the removal, were cut up fine with scissors into a watch glass with a cover. The whole was weighed, then one part of the minced tissue was transferred to a mortar in which the tissue was ground with sand, while the other part of the tissue was used for the determination of water content. After grinding, the mass of tissue and sand in the mortar was transferred to an Erlenmeyer flask using a minimal amount of water (about $10 \mathrm{cc}$. was used to transfer about 3 grams of the ground tissue). The extraction of the lipids was first carried out with two portions of alcohol-ether mixture ( 3 parts alcohol and 1 part ether) for 10-15 minutes each, then with ether for 5 minutes with return condenser on the steam bath. The extracts were made so that about $1 \mathrm{gram}$ of the moist tissue was contained in $100 \mathrm{cc}$. of the solvent.

The methods of lipid analysis were as follows: phospholipid, Bloor's oxidative method (14); total fatty acids, Bloor's oxidative method (15); cholesterol, both colorimetric and oxidative methods, but later the oxidative method (16) only. Neutral fat was calculated by subtracting the 
fatty acids of the phospholipid and cholesterol ester from the total fatty acids according to the following formula:

Fat F. A. = Total F. A. - Phospholipid F. A. (2/3 of the weight of phospholipid) - Cholesterol ester F. A. (43 per cent of the weight of ester)

The "residual unsaponifiable substance" was calculated by subtraction of the total cholesterol from the total unsaponifiable substance which was determined by the following procedure:

An aliquot of the lipid extract was saponified with 2 cc. sodium ethylate ( 2.5 grams metallic sodium in $100 \mathrm{cc}$. absolute alcohol) by heating on the steam bath almost to dryness, then acidified with dilute sulphuric acid and extracted with petroleum ether. The petroleum ether extract was transferred to a small separating funnel and to it was added the same amount of absolute alcoholic sodium ethylate (1 gram metallic sodium in $100 \mathrm{cc}$. absolute alcohol). It was shaken well, then water was added to make the concentration of alcohol in the funnel about 50 per cent, the mixture shaken well again and left for a while. At this concentration of alcohol, the fatty acids set free by saponification enter the alcohol fraction while the unsaponifiable fraction remains in the petroleum ether which separates from the dilute alcohol. The alcohol fraction was washed with a small amount of petroleum ether again. Both of the petroleum ether fractions were combined in a glass stoppered Erlenmeyer flask, evaporated to dryness on the steam bath removing the last trace of the petroleum ether by a gentle current of the air and the lipid content determined by Bloor's oxidative method (15). The material was calculated as cholesterol using the factor 3.90. Objection may be made to the use of this factor for the calculation since the nature of the residual unsaponifiable substances is unknown. However for the purpose of this comparison the above calculation is allowable. The procedures for the separation are modifications of those of Kumagawa and Suto (18).

To test the recovery of unsaponifiable substance, cholesterol in this case, a lipid mixture containing known amounts of oleic acid and cholesterol was prepared and a separation made according to the directions above. It was found that the recovery was complete to within a small fraction as the following results show:

Total unsaponifiable substance

$\begin{array}{ccc}\begin{array}{c}\text { Theoretical } \\ m g m .\end{array} & \begin{array}{c}\text { Found } \\ m g m .\end{array} & \begin{array}{c}\text { Difference } \\ \text { per cent }\end{array} \\ 1.85 & 1.87 & +1 \\ 1.85 & 1.81 & -2 \\ 1.47 & 1.46 & -0.8 \\ 1.47 & 1.43 & -3 \\ 1.47 & 1.38 & -6\end{array}$

The results of the lipid analysis of various tumors are given in Table I. 


\section{DISCUSSION}

The lipid content of various tumors is considerably different according to the nature of the tumors as shown in Table $I$. The high content of phospholipid in cancers, particularly in human cancers compared with other tumors is especially striking. The cholesterol content seems

TABLE I

Lipid content of tumors

(The content is expressed in grams per 100 grams dry tissue)

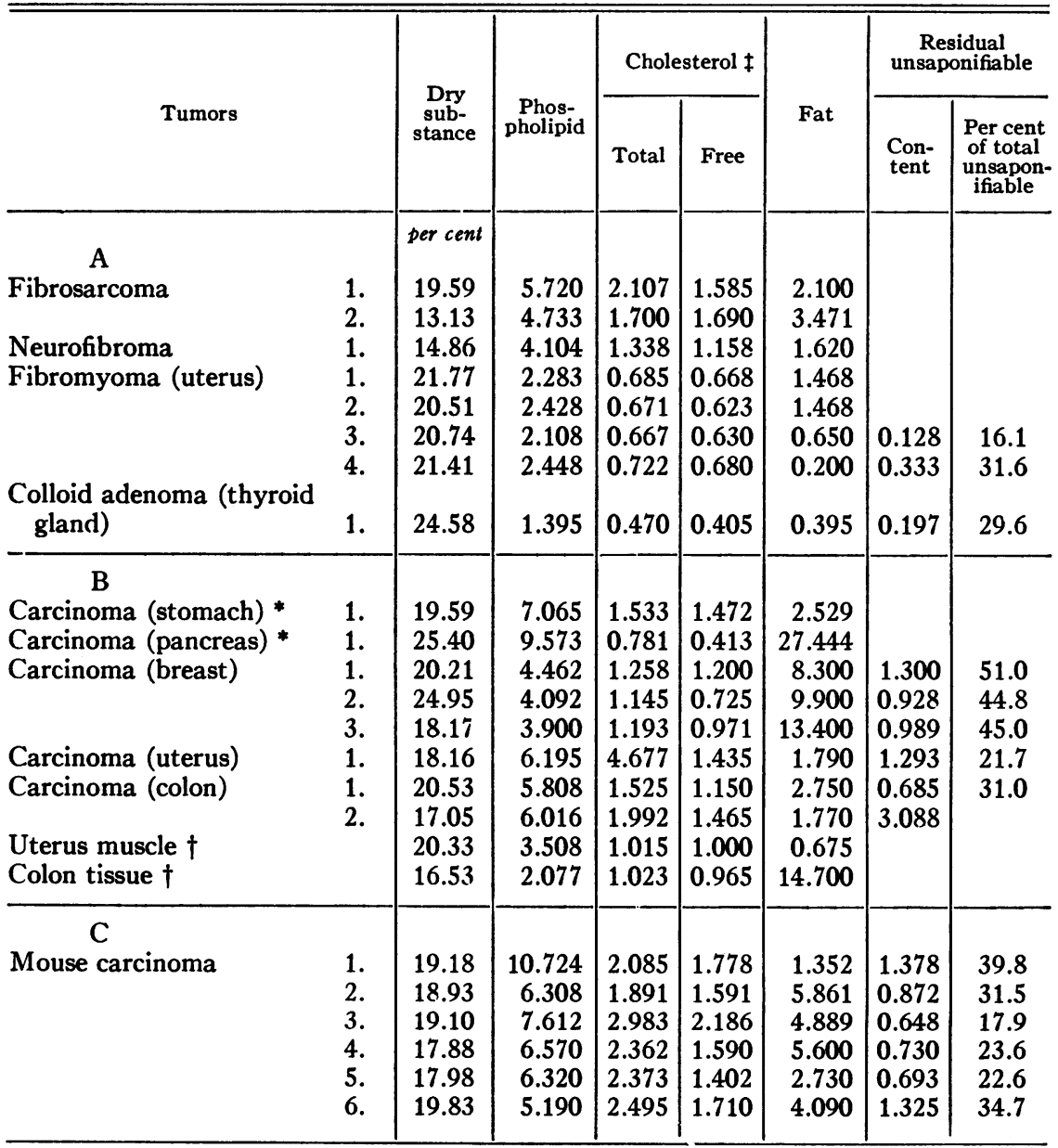

A. Human tumors other than cancer. B. Human cancers. C. Mouse cancers.

* Tumors obtained at autopsy.

$\dagger$ Muscle of the uterus, mucosa and submucosa of the colon near the tumors which were analysed.

$\ddagger$ Cholesterol was determined by the oxidative method. 
higher in cancers than in the others, but not so high as the phospholipid. In two cases of human cancer, colon and uterus cancer, the lipid content of these tumors were compared with those of the mother tissues upon which the tumors were growing and it was found that the phospholipid content of these malignant tumors was much higher than that of the mother tissues. The residual unsaponifiable substances were not determined in all tumors due to the lack of material.

\section{SUMMARY}

It is difficult, strictly speaking, to classify tumors into malignant and benign ones. The transplantable mouse carcinoma may also be greatly different from the human carcinoma. However, the tumors of Group A may be classified as mostly benign, whereas Group B and probably $\mathrm{C}$ are no doubt malignant. If this classification be granted, the following can be stated as the summary of this experiment.

Malignant tumors contain a much higher percentage of fatty substances-neutral fat, phospholipid and cholesterol-than the less malignant ones, a high phospholipid content being especially characteristic of malignancy.

The writers wish to express their cordial thanks to Drs. J. J. Morton and W. J. M. Scott of the Surgical Department and to Dr. K. M. Wilson of the Gynæcological Department of this Medical School for providing materials of this experiment.

Note. Since this work was first reported (17) there have appeared two pieces of work on the same topic by LeMay (19) and Bierich, Detzel and Lang (20). The results are similar to those reported above and so need not be discussed, but taken together these investigations leave little room for doubt that malignant tumors are characterized by a much higher content of phospholipid and probably of cholesterol than benign tumors or than the corresponding normal tissues.

\section{BIBLIOGRAPHY}

1. Roffo, A. H., Cancer Rev., 1930, v, 114, (abstract). Absorption of Cholesterol by Tumors.

2. Mattick, W. L., and Buchwald, K. W., J. Cancer Res., 1929, xiii, 157. Blood Cholesterol Studies in Cancer. IV. With Special Reference to Other Lipoid Partitions.

3. Kahn, H., Klin. Wchnschr., 1925, iv, 178 and 222. Die Chemischen Veränderungen bei Krebskranken und ihre Bedeutung für die Serodiagnostik der Malignen Geschwülste.

4. Bolaff, A., Ztschr. f. Krebsforsch., 1929-30, xxx, 170. Der Cholesteringehalt der Carcinommäuse.

5. Burgheim, F., Klin. Wchnschr., 1929, viii, 828. Über Beziehungen Zwischen Krebs und Lipoidstoff wechsel.

6. Haam, E., and Stöhr, R., Klin. Wchnschr., 1929, viii, 2382. Über den Phosphorgehalt des Blutes beim Infektiösen Hühnersarkom (Peyton Rous).

7. Enselme, and Enselme, J. (Mme.), Compt. rend. Acad. d. sc., 1927, clxxxiv, 1353. Contribution à la Chimie du tissu cancéreux. 
8. Roffo, A. H., and Correa, L. M., Bull. Soc. chim. biol., 1930, xii, 1247. La formation des lipides phosphorés au cours de L'autolyse des tissus normaux et néoplasiques.

9. Bullock, W. E., and Cramer, W., Proc. Roy. Soc. London, B, 1914, xxxvii, 236. The Lipoids of Transplantable Tumors of the Mouse and Rat.

10. Maisin, J., Ann. Surg., 1931, xciii, 180. Susceptibility and Resistance to Tar Cancer.

11. Rondoni, P., Ztschr. f. Krebsforsch., 1930, xxxii, 416. Die Einwirkungen verschiedener Lipoide auf das Wachstum des Mäusekrebses.

12. Friedberger, E., and Simke, R., Ztsch. f. Krebsforsch., 1930, xxxi, 437. Tumorwachstum und Ernährung.

13. Caspari, W., and Ottensooser, F., Ztschr. f. Krebsforsch., 1930, xxxii, 74. Über den Einfluss der Kost auf das Wachstum von Impfgeschwülsten.

14. Bloor, W. R., J. Biol. Chem., 1929, lxxxii, 273. The Oxidative Determination of Phospholipid (Lecithin and Cephalin) in Blood and Tissues.

15. Bloor, W. R., J. Biol. Chem., 1928, lxxvii, 53. The Determination of Small Amounts of Lipids in Blood Plasma.

16. Yasuda, M., J. Biol. Chem., 1931, xcii, 303. Contributions to the Micro Determination of Cholesterol.

17. Yasuda, M., Proc. Soc. Exp. Biology and Medicine, 1929-30, xxvii, 944. Lipoid Metabolism of Tumors.

18. Kumagawa, M., and Suto, K., Biochem. Ztschr., 1908, viii, 212. Ein neues Verfahren zur quantitativen Bestimmung des Fettes und der unverseifbaren Substanzen in tierischem material nebst der Kritik siniger gebräuchlichen methoden.

19. Le May, Neoplasmes, 1931, x, 158. Lipoides et Cancer.

20. Bierich, R., Detzel, A., and Lang, A., Ztschr. f. physiol. Chem., 1931, cci, 157. Über den Lipoidgehalt bösartiger Geschwülste. 